\title{
NAUTILUS POMPILIUS.
}

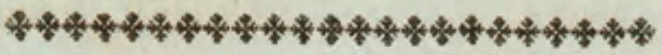

Character Genericus.

Animal (Rumph.mus, t. 17.f. в.)

Testa univalvis isthmis perforatis concamerata, polythalamia.

Lin. Syst. Nat. p. 1161.

CHARACTER SPECIFICUS, Eंc.

NAUTILUS testæ apertura cordata, anfractibus obtusis lævibus.

Lin. Syst. Nat. Gmel. p. 3369.

Cochlea margaritifera.

Rondel. aq. p. 97.

NAUTILUS major crassus.

Rumph. mus. t. 17. f. A. c.

Non possit non contemplantis animum percellere, quæ leviter interdum variata per universum genus pervadit Nautili Pompilii interna conformatio; cujus singula camera seu divisio cum illa quæ proxime adjacet, tubulo brevi et aperto connectitur, cellula prima et præcipua, cæteris multo ampliore, habitaculum, ut videtur, corpori animalis incolentis præbente ; 
bente; cujus animalis vera natura usque in hunc diem non satis accurate explorata est. Licet inditum sit huic testæ nomen Nautili genericum, non tamen in aquis navigare potest Pompilius, more istius quæ Argonauta Argo, seu Nautilus papyraceus communiter nominatur; cum qua tamen a nonnullis scriptoribus confundi videtur: Crescere non raro solet in magnam molem Nautilus Pompilius, in maribus Indicis præcipue repertus. 


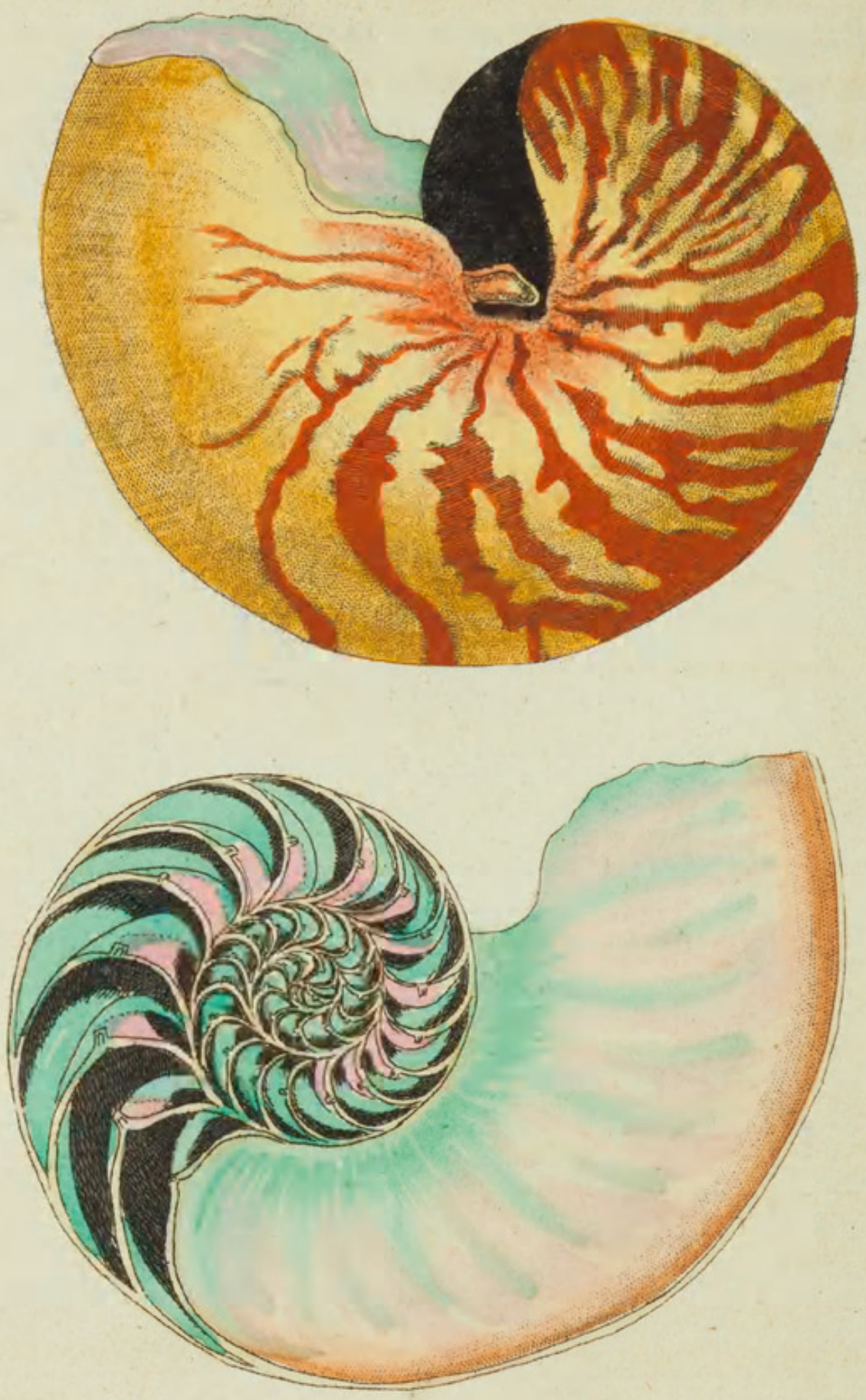
THE

\section{GREAT NAUTILUS.}

$* * 4 * * * * * 4 * 4 * 4 * 4 * 4 * 4 * 4 * 4 *$

\section{GENERIC CHARACTER.}

Animal not perfectly known.

Shell univalve, divided internally into a great many concentric cells, communicating by short tubes.

\section{SPECIFIC CHARACTER, छC.}

Whitish NAUTILUS with yellow-brown transverse bands, smooth spires, and cordated aperture.

The great pearly NAUTILUS.

The Chambered NAUTILUS.

The curious structure of this shell, (and which also runs, with some variation, thro' the whole genus, ) cannot be contemplated without admiration ; each cell or camera communicating with the next by a small and short open tube, the first or principal cell being far larger than the rest, and appearing destined to contain the chief part or body of the inhabiting animal, the nature of which is not yet properly understood. The Nautilus Pompilius is a native 
native of the Indian seas, and frequently arrives at a very considerable size. Notwithstanding its title, the Nautilus does not possess the power of sailing. on the surface in the manner of the Argonauta Argo, or Paper-Nautilus, with which it sometimes appears to be confounded in the works of authors. 


\section{$2 \mathrm{BHL}$ Biodiversity Heritage Library}

Shaw, George. 1801. "The Great Nautilus, Nautilus pompilius [PI. 515]." The Naturalist's Miscellany 13(CXLV), https://doi.org/10.5962/p.310961.

View This Item Online: https://www.biodiversitylibrary.org/item/281546

DOI: https://doi.org/10.5962/p.310961

Permalink: https://www.biodiversitylibrary.org/partpdf/310961

\section{Holding Institution}

Museums Victoria

\section{Sponsored by}

Atlas of Living Australia

\section{Copyright \& Reuse}

Copyright Status: Public domain. The BHL considers that this work is no longer under copyright protection.

This document was created from content at the Biodiversity Heritage Library, the world's largest open access digital library for biodiversity literature and archives. Visit BHL at https://www.biodiversitylibrary.org. 